\title{
ACMECS 정상회담 결과
}

태국 탁신 총리는 지난 11월 2 3일간 캄보디아, 라오스, 미얀마 및 베트남 정상들을 방콕으로 초청, 제2회 'Ayeyawady-Chao Phraya-Mekong Economic Cooperation Strategy(ACMECS)' 정상 회담을 개최하고 선언문을 채택한 바 그 결과는 아래 와같음.

\section{1. 선언문 주요 내용}

\section{가. 우선순위분야 협력 강화}

ㅁㅁㅁ역 및 투자 촉진을 위한 노력 경주

-5 개 회원국 역내 무역 및 투자에 대한 장벽 제거 ※ 태국은 타 회원국들로부터 수입되는 농산물 중 콩, 옥수수 등 10 개 품목에 대한 관세 유예를 약속

- 국경지역에 도매시장 및 물류센터 설치

- 공동사업협의체(Joint Business Council)의 역 할 장려 및 지원

- 정부와 기업체에 의한 공동 무역 · 투자 촉진활
동 장려 및 지원

ㅁ 공업 및 농업 발전을 위한 협력 강화

- 계약농업(contract farming)에 관한 협력 확대 - 안정적인 에너지 확보를 위한 포괄적인 에너지 계획 수립 및 이행

- 국경지대의 공업단지 또는 특별경제지대 조성 에 사기업체의 참여 유도

ㅁ원활한 교통·유통망 조성을 위한 노력 지속

-5 개 회원국 역내에 다양한 형태의 운송망 구축

- 관광 육성을 위한 항공노선 확대 및 인적자원개 발 촉진

- 한 국가에서 비자를 받으면 5 개 회원국에서 모 두 통용되는 '단일비자(single visa)' 제도 도입 ※ 우선 태국과 캄보디아가 단일비자에 관한 양해 각서 체결(6개월 이후 발효)

- 대학과 연구기관간의 네트워크 조성

\section{나. 공중보건 증진을 위한 노력 강화}


ㅁ 'AI 및 전염병 퇴치를 위한 동반자관계 선언' 에 명시된 조류인플루엔자(AI)를 비롯한 전염병 퇴치 를 위한 공조 강화

- 백신공동개발, 공공교육 캠페인, 정보와 전문인 력 공유, 백신 및 항바이러스성 약품 비축 등

ㅁ 공중보건기관간의 네트워크를 구축하고, 전염병 확산 억제 및 충격 완화를 위한 협력분야 및 조치 사항 모색

\section{다. 기술도입 촉진}

ㅁ '단일비자' 제도 가속화를 위한 IT 시스템 개발

ㅁ국경지대 검문소에서 활용 가능한 전자결재( $\mathrm{e}^{-}$ approval) 시스템 개발

ㅁ 오지 주민들을 위한 원격 진료제 및 원격 교육 도입

\section{라. ACMECS 강화}

ㅁ 국경지대에 자매도시 결성을 지속적으로 추진

행동계획(Action Plan) 갱신을 위한 장관급 회의 개최

$\mathrm{ACMECS}$ 활동을 장려하고 조율하기 위한 메카 니즘 구축

- 공식 웹사이트 개설, 실무조정그룹 결성, 실무 자급 비공식 조정회의 개최 등

ㅁ 개발파트너와의 파트너십을 강화하고, 역내 다른 협의체와의 상호보완 관계 유지

※ 탁신 총리는 11.4 (금) 기자회견을 통해 동남아

시아 지역의 조류 인플루엔자(AI) 퇴치를 위해 1 억바트(2.5백만불)를 Seed Money로 제공할
예정임을 공표함.

- 상기 기금은 동남아 역내 AI 발생시 백신과 치 료약, 의료기자재 및 의료요원 파견 비용 등에 사용

\section{2. 제3회 $\mathrm{ACMECS}$ 정상회담 개최 계획}

2006년 11월 캄보디아 앙코르와트에서 관광진흥 행사를 열고, 제 3 차 정상회의는 2007년 베트남 하 노이에서 개최하기로 결정함.

\section{3. 관찰결과}

\section{가. 태국의 주도적인 역할 수행}

ㅁ 동 ACMECS 정상회담은 태국 탁신 총리가 2003 년에 인도차이나반도 5 개국의 경제를 하나의 경 제권으로 통합하기 위하여 처음으로 제안하여 2003년 11월 미얀마에서 제1회 정상회담을 가진 바 있음.

2004년 10월 태국은 종래 수원국에서 원조공여국 으로 전환하면서 ACMECS 4개 회원국들에 대한 원조를 대폭 확대하고 동남아 5 개국을 단일 경제 협력권으로 통합해 나가는 것을 $\mathrm{ODA}$ 사업의 중심 축으로 하고 있음.

ACMECS 지역은 이미 태국의 바트화가 통용되는 통화권내에 있으며 앞으로 단일비자제도 도입을 비롯한 각종사업을 추진하게 될 경우 동 지역에 대 한 태국의 영향력이 더욱 확대될 것으로 전망됨.

\section{나. ACMECS에 선진국 자금의 투자}

ㅁ 태국은 단독으로 ACMECS 협력사업의 소요자금 
을 지원하기 어렵다는 점을 인식하고, 주변국의

인프라 개발에 소요되는 자금을 $\mathrm{ADB}$ 등 국제기구 와 프랑스, 일본 등 선진국으로부터의 투자유치도 적극 추진하고 있으며 한국측에 대하여도 기회 있 을 때마다 참여를 권유하고 있음.

ㅁ 일부 선진국에서는 ACMECS 협력사업의 본격화 에 대비하여 현재 큰 관심을 보이고 있음.

\section{4. 평가}

ACMECS 사업이 성공할 수 있을지는 아직 예단 하기 어려우나 태국 주도의 동 사업 성공여부는 태국의 경제능력에 상당히 좌우될 것으로 보임.

ㅁ 그러나 우리나라로서는 태국이 꾸준한 경제성장 세를 보이고 있고 동남아에서의 주도적 지위도 계 속 유지할 것으로 전망되는 만큼 동 지역에 대한 지속적 관심은 필요하다고 사료됨.

[자료 :주태국 대사관] 